\title{
PENYULUHAN PENINGKATAN PELAYANAN ADMINISTRASI KEPENDUDUKAN DALAM PEMBUATAN SURAT KETERANGAN WARIS DI DESA BLENDUNG DAN DESA KORANJI, KECAMATAN PURWADADI, KABUPATEN SUBANG, PROVINSI JAWA BARAT MENURUT HUKUM POSITIF
}

\author{
Utarie, F., Djakaria, M. dan Sandra, E. \\ Dosen Fakultas Hukum Universitas Padjadjaran
}

\begin{abstract}
ABSTRAK
Administrasi kependudukan di suatu Negara sangat berguna bagi Surat Keterangan Waris (SKW) yang akan menetukan hak bagi ahli waris untuk mendapatkan harta peninggalan dari pewaris. Kepala Desa memiliki kewenangan dalam pembuatan SKW, hanya saja terkadang hal ini tidak mencerminkan rasa keadilan. Hal ini muncul akibat ketidaktahuan dari masyarakat dan aparat, sehingga perlu adanya penyuluhan Hukum. Menjadi tanggung jawab bagi civitas academica untuk memperkenalkan sistem hukum yang dikenal di Indonesia, secara garis besar dipengaruhi oleh 3 hukum, yaitu hukum adat, hukum Islam, dan hukum Barat. Pencapaian penyuluhan hukum dapat dianggap telah optimal, dilihat dari tingkat kehadiran peserta dan tanya jawab peserta.
\end{abstract}

Kata kunci: Sistem hukum, SKW, waris, dan administrasi kependudukan

\begin{abstract}
Certificate of Inheritance will determine the rights of heirs to get the inheritance from the heir. The village chief has the authority in making Certificate of Inheritance, it's just sometimes it does not reflect a sense of justice. It arises due to the ignorance of the public and officials, so the need for counseling law. The responsibility for the academic community to introduce a legal system that is known in Indonesia, largely influenced by three laws, namely customary law, Islamic law and Western law. Achievement of legal education can be considered optimal, judging from the attendance of participants and participant debriefing.
\end{abstract}

Key words: legal system, SKW, inheritance, and population administration

\section{PENDAHULUAN}

Negara Kesatuan Republik Indonesia berdasarkan Pancasila dan Undang-Undang Dasar Negara Republik Indonesia Tahun 1945 pada hakikatnya berkewajiban untuk memberikan perlindungan dan pengakuan terhadap penentuan status pribadi dan status hukum setiap Peristiwa Kependudukan dan Peristiwa Penting yang dialami oleh penduduk yang berada di dalam dan atau di luar wilayah Negara Kesatuan Republik Indonesia. Administrasi kependudukan di Indonesia merupakan hal yang sangat berperan dalam pembangunan, dari sistem administrasi penduduk dapat diketahui tentang data-data penduduk dan informasi yang sesuai dengan keadaan penduduk dan kondisi daerah tempat tinggal penduduk.

Status hukum diberikan untuk memberikan jaminan kepada penduduk agar memperoleh keadilan. Keadilan merupakan tujuan dari usaha penegakan hukum. Tiga unsur dalam menegakkan hukum dan keadilan adalah: (Lopa, 1987:4)

1. diperlukan adanya peraturan hukum yang sesuai dengan aspirasi masyarakat.

2 . adanya aparat penegak hukum yang profesional dan bermental tangguh atau memiliki integritas moral yang terpuji.

3. adanya kesadaran hukum masyarakat yang memungkinkan dilaksanakannya penegakan hukum.

Peristiwa Kependudukan memerlukan bukti yang sah untuk dilakukan pengadministrasian dan pencatatan sesuai dengan ketentuan undang-undang. Penyuluhan hukum yang dilaksanakan dosen dan MahasiswaKKN, memfokuskanmengenaipentingnya kesadaran dalam pembuatan Surat Keterangan Waris (SKW) yang merupakan ranah administrasi kependudukan. Masyarakat diharapkan dapat sadar akan hak dan kewajibannya, serta mengetahui pentingnya ketaatan terhadap administrasi.

Hukum Waris adalah hukum yang mengatur mengenai apa yang terjadi dengan harta kekayaan seseorang yang telah meninggal dunia, dengan lain perkataan mengatur peralihan harta kekayaan yang ditinggalkan seseorang yang meninggal serta akibatakibatnya bagi ahli waris. Substansi Keterangan Hak Waris berkaitan dengan siapa pewaris dan ahli waris, serta bagaimana susunan para ahli warisnya yang menerangkan atau menyatakan dihadapan Notaris atau pejabat lain yang bersangkutan, mengenai bagian atau hak masing-masing para ahli waris, tergantung pada hukum waris yang akan mereka gunakan, sedangkan dalam pembagian warisnya, dapat dibuat akta pembagian hak waris tersendiri, yaitu berupa Keterangan Hak Waris, yang menunjukkan bagian (hak) tertentu atas harta peninggalan pewaris (warisan) yang ada.

Pembuatan Keterangan Hak Waris (KHW) menurut golongan penduduk didasarkan pada:

1. Asas konkordansi Pasal 13 Wet op de Groolboeken dcr Nationale Schuld (Undang-Undang tentang Buku Besar Perutangan Nasiona!) di Belanda;

2. Surat Edaran Departemen Dalam Negeri Direktorat Jenderal Agraria tanggal 20 Desember 1969 No. Dpt/12/63/69

3. Fatwa Mahkamah Agung, atas permintaan dan ditujukan kepada Ny. Sri Redjeki Kusnun, SH, tertanggal Jakarta, 25 Maret 1991 No. KMA7041/01/1991 jo, Surat Ketua Mahkamah Agung kepada Ketua Pengadilan Tinggi, Pengadilan 
Tinggi Agama, Pengadilan Negeri dan Pengadilan Agama di seluruh Indonesia tertanggal Jakarta, 8 Mei 1991 No. MA/Kumdil/171/V/K/1991

4. Peraturan Pemerintah Nomor 24 Tahun 1997 Tentang Pendaftaran Tanah, Pasal 42 ayat 1 juncto Peraturan Menteri Necgara Agraria/Kepala Badan Pertanahan Negara Nomor 3 Tahun 1997 Tentang Ketentuan Pelaksanaan PP Nomor 24 Tahun 1997, Pasal 111 ayat 1 huruf c angka 4. (Satrio, 1992: 2)

Perlu kita pahami bahwa banyaknya instansi yang terkait dalam pembuatan Surat Keterangan Waris tidak dapat dilepaskan dari kondisi hukum warisnya. Hal ini secara jelas terlihat dari berbagai peraturan yang mengakui eksistensi Surat Keterangan Waris yang dibuat oleh instansi yang berbeda sesuai dengan hukum yang berlaku. Pemberlakuan satu sistem hukum waris bagi seluruh warga negara Indonesia sebagai salah satu upaya menuju unifikasi agar tidak terjadi perbedaan golongan penduduk dalam proses pendaftaran tanah, berangkat dari kemajemukan dan kayanya hukum Waris di Indonesia. Sehingga setidak-tidaknya Surat Keterangan Waris ini diseragamkan fungsi dan tujuan pembuatannya.

Hukum waris, bukti surat akan menjadi bukti yang penting dan utama dibandingkan alat bukti lain. Mengacu pada ketentuan pasal 1866 dan pasal 1867 KUHPer, maka pembuktian dengan tulisan dilakukan dengan tulisan baik otentik maupun di bawah tangan. Sebenarnya bukti ahliwaris yang merupakan bukti perdata tidak tepat jika dikeluarkan oleh Pejabat yang tunduk pada Hukum Administrasi. (Adjie, 2008) Berdasarkan Surat Keterangan Waris inilah nantinya para ahli waris mempunyai "alasan hak" untuk menuntut warisan. Untuk mengetahui "alasan hak" ini maka perlu diketahui perihal subyek dan obyek hukum waris dalam kaitannya menuju Surat Keterangan Waris yang uniform.

Subyek hukum waris merupakan hal yang sangat esensial mengingat Surat Keterangan Waris ini sebagai alat bukti bagi pihak-pihak yang mengklaim dirinya sebagai ahli waris, dan pada gilirannya berfungsi sebagai dasar untuk menuntut hak tertentu atas benda atau hak kebendaan sebagai objek waris. Secara prinsip sistem hukum waris baik BW, Hukum Adat dan Hukum Islam telah menentukan siapa saja yang dimasukkan sebagai ahli waris.

Mengenai obyek warisan, dalam hukum adat dan hukum waris Islam yang menjadi hak para ahli waris adalah harta kekayaan bersih setelah dikurangi segala kewajiban pewaris. Obyek waris ini khususnya benda-benda yang peralihannya harus dilakukan dengan formalitas tertentu, misalnya rumah/tanah. Dalam hal obyek warisan adalah benda bergerak maka ketiadaan Surat Keterangan Waris ini tidak relevan. Sesuai dengan Pasal 4 (1) dari Instruksi Warde Governement Land Mates, Stb 1916 No.517 dari Intruksi Balai Harta Peninggalan tersebut di atas, bahwa diperlukan Surat Keterangan Waris dari Balai Harta Peninggalan bagi golongan penduduk Timur Asing untuk proses balik nama para ahli waris. Selain itu digunakan untuk mendaftarkan dan membuka surat wasiat. Selain fungsi di atas Surat Keterangan Waris sebagai surat keterangan dalam kaitan untuk proses setiap perjanjian yang bermaksud memindahkan hak atas tanah, memberikan sesuatu hak baru atas tanah, menggadaikan tanah atau meminjam uang dengan hak atas tanah sebagai tanggungan harus dibuktikan dengan suatu akta yg dibuat oleh dan dihadapan PPAT.

\section{SUMBER INSPIRASI}

Penyuluhan hukum yang dilaksanakan sebagai upaya peningkatan pelayanan administrasi kependudukan dalam pembuatan Surat Keterangan Waris di Desa Blendung dan Desa Koranji, Kecamatan Purwadadi, Kabupaten Subang, Provinsi Jawa Barat Menurut Hukum Positif. Aparat desa yang memiliki kewenangan dalam pembuatan SKW diharapkan mengetahui sistem-sistem pembagian warisan.

\section{METODE}

Metode yang akan digunakan untuk mencapai tujuan yang telah dicanangkan adalah pendidikan masyarakat melalui cara di bawah ini:

1. Survey wilayah sebagai tempat mengadakan penyuluhan hukum;

2. Ceramah, diskusi panel, dan sesi tanya jawab.

\section{KARYA UTAMA}

Surat keterangan waris pada dasarnya merupakan keputusan yang memberikan penetapan seseorang sebagai ahli waris atau bukan. Penyelenggaraan penerbitan surat keterangan waris sangat erat hubungannya dengan perdata khususnya hukum waris dan hukum harta perkawinan. Peristiwa kelahiran seseorang menimbulkan akibat hukum berupa hubungan hukum dengan orangtuanya, saudaranya, dan keluarga pada umumnya.

Berdasarkan Surat Keterangan Hak Waris tersebut nantinya akan dibuat suatu akta yang berisikan rincian pembagian harta peninggalan dari pewaris, misalnya rumah, tanah, dan lain-lain. Dalam Akta tersebut akan disebutkan nama-nama ahli waris berikut harta peninggalan yang menjadi bagiannya. Untuk membuktikan kedudukan seseorang sebagai ahli waris, diperlukan suatu dokumen yang menjabarkan ketentuan hukum waris tentang hal itu, yang dapat dipakai sebagai pegangan oleh para ahli waris maupun pejabat-pejabat yang berkaitan dengan pelaksanaan hukum waris, surat demikian tersebut yang kita sebut sebagai Surat Keterangan Waris. Surat Keterangan Hak waris tersebut sebagai awal bagi kelanjutan dibuatnya Akta Pembagian Harta Peninggalan.

Hukum kewarisan adalah himpunan aturan hukum yang mengatur tentang siapa ahli waris yang berhak mewarisi harta peninggalan pewaris. Mengenai aturan hukum yang mengatur kewarisan, negara Indonesia belum mempunyai hukum waris nasional. Dalam pewarisan yang berlaku di Indonesia sampai saat ini belum dapat diwujudkan dalam unifikasi hukum, oleh karenanya, sampai sekarang 
masih belum terdapat keseragaman pengaturan masalah warisan.

Surat Keterangan Hak Waris biasanya dibuat oleh Notaris yang berisikan keterangan mengenai pewaris, para ahli waris dan bagian-bagian yang menjadi hak para ahli waris berdasarkan Kitab Undang-Undang Hukum Perdata. Surat Keterangan Hak Waris tersebut sebagai awal bagi kelanjutan dibuatnya Akta pembagian Harta Peninggalan.

Berdasarkan kenyataan di masyarakat mengenai penggunaan Surat Keterangan Waris khususnya mengenai ahli waris pengganti yang ibunya meninggal lebih dulu acapkali sering diperlakukan "tidak adil" oleh perangkat desa. Masih minimnya pengetahuan tentang waris khususnya ahli waris karena penggantian tempat para aparat desa berpendapat bahwa ahli waris yang ibunya meninggal lebih dulu tidak berhak menerima warisan dari pewaris apabila masih ada ahli waris laki-laki (paman) sehingga menutup kedudukan ahli waris pengganti tersebut. Oleh karenanya para perangkat desa sering mencoret kedudukan ahli waris pengganti tersebut apabila ahli waris pengganti tersebut akan mengajukan Surat Keterangan Waris.

Surat Keterangan Waris masyarakat mengangggap tidak mengenal penggantian tempat dalam ahli waris khususnya yang ibunya meninggal lebih dahulu karena menurut perangkat desa, Hukum Islam tidak mengenal penggantian tempat. Sehingga dalam masalah pembagian warisan khususnya masalah tanah para ahli waris pengganti yang ibunya meninggal lebih dulu cenderung tidak mempersoalkan pembagian warisan atas tanah waris tersebut dan menyerahkan semua wewenangnya kepada ahli waris yang lain untuk dilakukan pembagian warisan tersebut. sebagaimana wawancara dengan seorang masyarakat Desa Koranji, Bapak Tukning, pada tanggal 17 Februari 2013.

Terhadap tanah warisan tersebut sebagian masyarakat mengatakan belum dilakukan pembagian sebagai mana wawancara dengan seorang masyarakat Desa Koranji, Ibu Arifin, pada tanggal 17 Februari 2013, artinya masih terjadi pemilikan tanah secara bersama atas tanah warisan tersebut. Dengan menanyakan pewaris meninggal dunia atau melihat surat kematian pewaris dan surat tanda bukti hak milik atas tanah atau sertifikat serta tanda bukti permohonan pendaftaran peralihan haknya.

Kebanyakan masyarakat kurang memiliki kesadaran untuk memperhatikan status kepemilikan tanah mereka. Mereka masih beranggapan jika harta benda yang dahulu adalah milik keluarga mereka akan selamanya menjadi milik mereka dan keturunanketurunan mereka, tanpa menghiraukan hukum yang berlaku. Jadi sering kita temui bahwa suatu keluarga hidup di atas tanah dan bangunan yang masih tercatat atas nama orang tua bahkan kakek mereka yang telah lama meninggal dunia. Masyarakat masih beranggapan bahwa orang yang memiliki tanah dan bangunan adalah pemilik tanah meskipun sertifikat hak atas tanahnya bukan atas nama orang yang menempati tanah melainkan masih atas namanya orang yang sudah meninggal dunia.

\section{ULASAN KARYA}

Adanya perlakuan yang sama bagi setiap orang dihadapan hukum membawa konsekuensi bagi penyelesaian perkara kewarisan. Pewarisan timbul sehubungan dengan meninggalnya pewaris. Kematian orang tersebut merupakan suatu peristiwa hukum. Peristiwa kematian bukanlah suatu perbuatan yang memungkinkan orang untuk melakukan pilihan hukum. Oleh karena peristiwa hukum tersebut maka diberberlakukan ketentuan hukum mengenai orang yang meninggal dunia khususnya tentang pewarisan.

Dalam hubungan ini yurisprudensi Mahkamah Agung Reg. Nomor 172K / Sip / 1974, tertanggal 6 Maret 1975 memutuskan: "Untuk menentukan cara pembagian harta warisan, hukum waris yang dipakai adalah bertitik tolak kepada agama yang dianut oleh si pewaris yang meninggalkan harta tersebut, yakni : apabila si pewaris yang meninggal beragama Islam, maka pembagian hartanya dilakukan menurut Hukum Islam dan apabila si pewaris yang meninggal beragama Kristen, maka pembagian hartanya dilakukan menurut Adat. (Ali, 1979).

Selanjutnya berdasarkan Pasal 2 dan Pasal 49 Undang-Undang Nomor 7 Tahun 1989 tentang Peradilan Agama Juncto Pasal 2 dan Pasal 49 UndangUndang Nomor 3 Tahun 2006 Tentang Amandemen Undang-Undang Peradilan Agama, lembaga peradilan yang memiliki kompetensi untuk mengadili perkara perdata orang Islam adalah Pengadilan Agama.

Pasal 2 Undang-Undang Nomor 7 Tahun 1989 Juncto UU Nomor 3 Tahun 2006 Tentang Administrasi Kependudukan menyatakan: "Peradilan Agama adalah salah satu pelaku kekuasaan kehakiman bagi rakyat pencari keadilan yang beragama Islam mengenai perkara perdata tertentu sebagaimana dimaksud dalam Undang-Undang ini."

Pasal 49 UU Nomor 7 Tahun 1989 Juncto UU Nomor 3 Tahun 2006 lebih lanjut menyatakan: "Pengadilan Agama bertugas dan berwenang memeriksa, memutus, dan menyelesaikan perkara di tingkat pertama antara orang-orang yang beragama Islam di bidang :
a. perkawinan;
b. waris;
c. wasiat;
d. hibah;
e. wakaf;
f. zakat;
g. infaq;
h. shadaqah; dan
i. ekonomi syari'ah."

Hukum kewarisan memegang peranan yang sangat penting, bahkan menentukan dan mencerminkan sistem kekeluargaan yang berlaku dalam masyarakat itu. Seperti diungkapkan Hazairin : "Dari seluruh hukum, maka hukum perkawinan dan kewarisanlah yang menentukan dan mencerminkan sistem kekeluargaan yang berlaku dalam masyarakat".

Kewarisan menurut hukum Islam ialah proses pemindahan harta peninggalan seseorang yang telah meninggal, baik (yang berupa benda yang wujud maupun 
yang berupa hak kebendaan, kepada keluarganya yang dinyatakan berhak menurut hukum). (Basyir, 1999) Dari batasan tersebut dapat diperoleh ketentuan bahwa menurut hukum Islam, kewarisan baru terjadi setelah pewaris meninggal dunia. Ketentuan tersebut telah dijelaskan dalam Al-Qur'an, dengan penjelasan yang sempurna sebagai landasan bagi hukum waris dan ketentuan pembagiannya dilengkapi dengan sunnah dan ijma. Akan tetapi tetap perlu diingat bahwa matinya muwaris (pewaris) mutlak harus dipenuhi.

Seseorang bisa disebut sebagai muwaris jika pewaris telah meninggal dunia. Itu berarti bahwa, jika seseorang memberikan harta kepada ahli warisnya ketika dia masih hidup, maka itu bukan waris (Rahman, 1996). Islam dalam hal ini sangat memperhatikan persoalan hukum waris yang telah dijelaskan secara terperinci dalam Al-Qur'an, karena hukum waris merupakan sarana pokok dalam hal pemilikan harta benda, sedangkan harta benda merupakan tulang punggung kehidupan individual maupun komunal. Dengan pembagian warisan yang Pemindahan harta orang yang meninggal dunia kepada ahli waris berlaku dengan sendirinya.

Ketentuan harta warisan yang terdapat dalam Al-Qur'an dan Hadist adalah merupakan ketentuan yang harus ditaati dan kaum muslimin wajib melaksanakannya. Dalam hal ini penulis berpegang pada ketentuan dalam surat An-Nisaa tersebut di atas dan selain itu Rasulullah SAW juga memerintahkan agar kita membagi harta pusaka menurut Kitab AlQur'an dalam sabdanya: "Bagilah harta pusaka antara ahli-ahli warts menurut Kitabullah (Al-Qur'an ). " (HR. Muslim dan Abu Dawud ). (Rahman, 1996)

Ahli waris pengganti yang biasa disebut plaatvervulling dalam hukum waris barat (menurut Kitab Undang-Undang Hukum Perdata) adalah apabila seorang ahli waris meninggal dunia lebih dulu dari si pewaris, maka ia akan digantikan kedudukannya atau hak dan kewajibannya sebagai waris oleh anak-anaknya. (Ramulyo, 252)

Penggantian waris dalam Hukum Adat lebih dikenal dengan Lembaga Hidup Waris, keturunan dari anak (ahli waris) yang meninggal mendahului pewarisnya, menerima porsi orang tuanya dari harta peninggalan kakeknya. Penggantian dalam hukum Adat dikenal dalam garis ke atas dan menurun. Hal ini berpangkal tolak bahwa harta keluarga sejak semula diperuntukkan sebagai dasar hidup materiil bagi mereka yang lahir dari keluarga yang bersangkutan, mendapatkan realisasinya di dalam penggantian tempat mendahului pewarisnya. (Sudiyat, 1981).

Wirjono Prodjodikoro berpendapat, bahwa: "Cucu perempuan, yaitu anak perempuan dari anak laki-laki kalau tidak ada anak laki-laki lain yang masih hidup mendapat setengah bagian dari harta warisan. Dua atau lebih cucu perempuan mendapat duapertiga bagian. Kalau ada anak laki-laki, cucu perempuan tidak mendapat bagian sama sekali."

Hukum Islam mengenal ahli waris pengganti dengan adanya "Hukuni Munasakhah" . As-Sayyid as Syarif menta'rifkan munasakhah ialah : memindahkan bagian sebagian ahli waris kepada orang yang mewarisinya, lantaran kematiannya sebelum pembagian harta peninggalan dilaksanakan. Beliau menta'rifkan demikian, karena arti lafadh munasakhah tersebut berasal dari suku kata "naskh" yang menurut pengertian bahasa berarti nacilu atau tahwil, yakni memindahkan.

Munasakhah menurut istilah ulama faraid ialah meninggalnya sebagian ahli waris sebelum pembagian harta waris sehingga bagiannya berpindah kepada ahli warisnya yang lain. Bila salah seorang ahli waris meninggal, sedangkan ahliwaris tersebut belummenerima hak warisnya (karena memang belum dibagikan) maka hak warisnya berpindah kepada ahli warisnya. Karena disini akan timbul suatu masalah yang oleh kalangan ulama faraid dikenal dengan sebutan al-jami'ah (ash Shabuni, 1995). Dari pengertian munasakhah tersebut dapat ditarik kesimpulan munasakhah mempunyai dua bentuk:

1. Ahli waris yang bakal menerima pemindahan bagian pusaka dari orang yang mati belakangan adalah ahli waris juga bagi orang yang mati duluan.

2. Ahli waris yang bakal menerima pemindahan bagian pusaka dari orang yang mati belakangan adalah bukan ahli waris bagi orang yang mati duluan. Yakni seandainya tidak terjadi kematian yang kedua, ahli waris tersebut tidak dapat mewarisi orang yang mati duluan.

Selanjutnya dengan adanya prinsip hukum munasakhah yang dianut oleh hukum waris Islam, para ahli berpendapat bahwa sepanjang tidak bertentangan dengan Al-Qur'an dan sunah Rasul, penggantian ahli waris tidak ada keberatan sedikitpun. Cucu dari anak perempuan tidak dibedakan kedudukannya dengan cucu dari anak laki-laki sebagai ahli waris mendiang kakek atau neneknya, bukan atas dasar rasa keadilan yang dapat menjadi pertimbangan ijtihad. (Sajuti Thalib, 1987).

Dalam hal ini, Hazairin mengembalikan kepada ketentuan nash Al Qur'an surat An-Nisaa' ayat 33 yang artinya: "Bagi tiap-tiap harta peninggalan dari harta yang ditinggalkan ibu bapak dan karib kerabat, Kami jadikan pewaris-pewarisnya [288] dan (jika ada) orang-orang yang kamu telah bersumpah setia dengan mereka, Maka berilah kepada mereka bahagiannya. Sesungguhnya Allah menyaksikan segala sesuatu."

Lebih lanjut menurut Hazairin, bahwa cucu baik laki-laki maupun perempuan menggantikan bapaknya, juga cucu laki-laki maupun perempuan menggantikan ibunya yang telah meninggal lebih dahulu dari si pewaris. (Hazairin, 1990) Kedudukan dan bagian warisan bagi ahli waris pengganti ini, di dalam ayatayat Al-Qur'an maupun Hadits Nabi sama sekali tidak menjelaskan perihal waris pengganti secara tegas dan terperinci. Dan untuk mengatasi hal ini, maka para ulama ahli hukum Islam berusaha dan berijtihad untuk menentukan kepastian hukurrmya. Ijtihad mereka itu dengan berdasarkan ketentuan yang telah ada dan prinsip hukum kewarisan Islam yang utama, yaitu keadilan serta pertimbangan akan kelangsungan hidup 
bagi keturunan dari ahli waris yang telah meninggal dunia tersebut atau penggantinya.

Kompilasi Hukum Islam Pasal 185 mengatur mengenai ahli waris pengganti, menyatakan bahwa:

1. Ahli waris yang meninggal lebih dahulu daripada pewaris maka kedudukannya dapat digantikan oleh anaknya, kecuali mereka yang tersebut dalam Pasal 173.

2. Bagian bagi ahli waris pengganti tidak boleh melebihi dari bagian ahli waris yang sederajat dengan yang diganti. “

Ulama-ulama masih berbeda pendapat tentang ahli waris pengganti yang terdapat dalam pasal tersebut. Akan tetapi jika yang di pandang sebagai ahli waris dalam hukum kewarisan Islam hanyalah mereka yang masih hidup, penggantian ahli waris tidak dapat berlaku umum, hanya mengenai kasus khusus atas pertimbangan khusus pula sebagai pengecualian. Dan karena kekhususan ini pula, dalam penyelesaian masalah mengenai waris pengganti menurut hukum waris Islam akan mengalami kesulitan untuk menentukan dan menetapkan pembagiannya.

\section{DAMPAK DAN MANFAAT}

Melalui kegiatan KKNM - PPMD Integratif dan penyuluhan hukum diharapkan tercapainya hasil, sebagai berikut:

1. Menambah pengetahuan warga masyarakat mengenai kesadaran pentingnya memiliki surat-surat kependudukan dan kesadaran dalam pembuatan Surat Keterangan Waris.

2. Memberikan sumbangan pemikiran dalam pengembangan Ilmu Hukum, khususnya bidang Hukum Keluarga terhadap tata cara waris dalam keluarga di Indonesia.

\section{SIMPULAN}

Berdasarkan pelaksanaan penyuluhan hukum yang telah dilakukan beberapa hal yang dapat disimpulkan, bahwa antusias warga terhadap permasalahan pewarisan cukup tinggi dilihat dari tingkat keikutsertaan warga dalam berpartisipasi saat penyuluhan. Selain itu, warga Desa Blendung dan Desa Koranji telah memahami pentingnya pengetahuan dalam system pembagian waris dan juga perlunya ketaatan terhadap administrasi.

Metode pendidikan masyarakat, cukuplah tepat dalam penyampaian ilmu hukum. Penyuluhan dengan terlebih dahulu melakukan preview terhadap permasalahan waris masyarakat, kemudian menyiapkan materi. Materi yang disampaikan dalam penyuluhan haruslah mudah dimengerti, singkat, dan nyata sehingga masyarakat dapat memahami dan mempraktikannya ilmu hukum kewarisan yang telah diberikan.

\section{PENGHARGAAN}

Kami mengucapkan terima kasih kepada semua pihak yang telah mendukung khususnya:

1. Kepala Desa Koranji, Bapak Nurtasim.

2. Kepala Desa Blendung, Bapak Sadjab.

3. Sekretaris Desa Koranji

4. Sekertaris Desa Blendung

\section{DAFTAR PUSTAKA}

Adjie, H. 2008. Pembuktian sebagai ahli waris dengan akta notaris. Bandung: C.V. mandar Maju.

Ali ash Shabuni. 1995. Hukum Waris menurut Al Quran, Bandung: Trigenda Karya.

Baharuddin Lopa. 1987. Permasalahan Pembinaan dan Penegakan Hukum di Indonesia, Jakarta: PT. Bulan Bintang.

Basyir, 1999. Hukum Perkawinan Islam, Yogyakarta: UII Pres.

Chidir Ali. 1979. Yurisprudensi Hukum Perdata Islam di Indonesia, Bandung: Al-Ma'arif.

Habib Adjie. 2008. Pembuktian Sebagai Ahliwaris dengan Akta Notaris, Bandung: C.V. Mandar Maju.

Hazairin. 1990 Hukum Kewarisan Bilateral Menurut Al-Qur'an dan Hadits, Jakarta: Tintamas.

Idris Ramulyo. 2004 Hukum Perkawinan, Hukum Kewarisan, Hukum Acaa Peradilam Agama, dan Zakat menurut Hukum Islam, Bandung: Sinar Grafika.

Iman Sudiyat. 1981. Hukum Adat Sketsa Asas, Yogyakarta: Liberty.

J. Satrio. 1992. Hukum Waris, Bandung: Alumni.

Otje Salman. 1993. Kesadaran Hukum Terhadap Hukum Waris, Bandung: Alumni.

Rahman. 1996. Karakteristik hukum Islam dan Perkawinan, Jakarta: Srigunting.

Sajuti Thalib. 1987. Hukum Waris Islam di Indonesia, Jakarta: Bina Aksara.

Wiryono Prodjodikoro. 1962. Hukum Warisan di Indonesia, Bandung's Gravenhage Vorkin'van Hoeve. 